\title{
Biozonation and Paleobathymetry on Foraminifera Upper Cretaceous Deposites of Central Iran Basins (Isfahan, Baharestan Section)
}

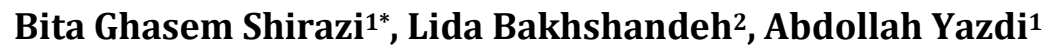 \\ ${ }^{1}$ Department of Geology, Kahnooj Branch, Islamic Azad University, Kerman, Iran \\ ${ }^{2}$ Department of Geology, Science and Research Branch, Islamic Azad University, Tehran, Iran \\ Email: ${ }^{*}$ itashirazi49@yahoo.com
}

Received 29 May 2014; revised 25 June 2014; accepted 20 July 2014

Copyright (C) 2014 by authors and Scientific Research Publishing Inc.

This work is licensed under the Creative Commons Attribution International License (CC BY). http://creativecommons.org/licenses/by/4.0/

(c) (i) Open Access

\begin{abstract}
In this study Late Cretaceous stratum in central Iran, Baharestan section in Isfahan area, was evaluated by biozonation and paleobathymetry. These sediments have 89 meters thick, and strata have been formed of marl and marl limestone. In order to indicate the ancient depth of Upper Cretaceous at this time, planktonic and benthic foraminifera were studied. The percentage of the total planktonic foraminifera to the whole sample of foraminifera after the removal of indwell benthic foraminifera $\left(\% P^{*}\right)$ using the formula $D=e\left(3.58718+\left(0.03534 \times \% P^{*}\right)\right)$ was identified and depth of 200 - 450 meters was achieved for them. In the present investigation, 30 planktonic species of 11 genus have been identified. The Upper Cretaceous deposit was divided to 6 biozones on the basis of planktonic foraminifera which are cosmopolitan and consist of: Biozone 1-Marginotruncana sigali-Dicarinella primitiva partial range zone; Biozone 2-Dicarinella concavata interval zone; Biozone 3-Dicarinella asymetrica total range zone; Biozone 4-Globotruncanita elevata partial range zone; Biozone 5-Globotruncana ventricosa interval zone; Biozone 6-Radotruncana calcarata interval zone. Based on planktonic foraminifera, the Upper Cretaceous sediments in the study area are of the Turonian-Late Campanian ages.
\end{abstract}

\section{Keywords}

Biozonation, Foraminifera, Central Iran, Paleobathymetry, Turonian, Late Campanian

\footnotetext{
${ }^{*}$ Corresponding author.
}

How to cite this paper: Shirazi, B.G., Bakhshandeh, L. and Yazdi, A. (2014) Biozonation and Paleobathymetry on Foraminifera Upper Cretaceous Deposites of Central Iran Basins (Isfahan, Baharestan Section). Open Journal of Geology, 4, 343-353. http://dx.doi.org/10.4236/ojg.2014.48026 


\section{Introduction}

Distribution of benthonic and planktonic foraminifera in the sediments of Santonian-Campanian Baharestan section located in central Iran has been examined.

The purpose of this study is precise investigation and identification of ecological zones and quantitative study of planktonic foraminifera of sediments in our studies.

These sediments with the depth of 89 meters are formed of limestone and limy marl which has SantonianCampanian stand on the planktonic foraminifera. These sediments have been introduced as Echinids marls in the study area.

\section{Geographical Location and Access Roads of Baharestan Section}

Baharestan section is located at 27 kilometers south of Khavarshahr Isfahan and has geographic location of $51^{\circ} 49^{\prime} 08^{\prime \prime}$ eastern longitude and 36 09'30" north latitude. This section is in the map on 1:250,000 Isfahan (Figure 1). The access road of this section is possible through old asphalt Isfahan-Shiraz road that after 25 kilometers reaches Baharestan city. Then through the dirt road towards the limestone quarry of Lashtar, access to the section is possible. The study section is located in the north of the mine (Figure 2).

\section{Characteristics of the Lithostratigraphic Units of Echinids Marls in Baharestan Section}

This unit in Baharestan contains 89 meters of gray limestone and limy marl. The layers of this unit have a trend of N50W and gradient of 40NE which the slope gradually reduces towards the top of the formation. This unit similar to other inoceramus limestones, unlike the younger units’ Cretaceous layers through regional tectonics has a negative slope towards the northeast (Aghanabati, 2005) [1].

Lower boundary of this unit is conformable with Inoceramus limestones and its upper boundary is conformable with organic limestone (Figure 3).

In Baharestan section the Echinids marls unit includes lithostratigraphy unites from bottom to top (Figure 4):

Biological characteristics of the Echinid marl unit in Baharestan section:

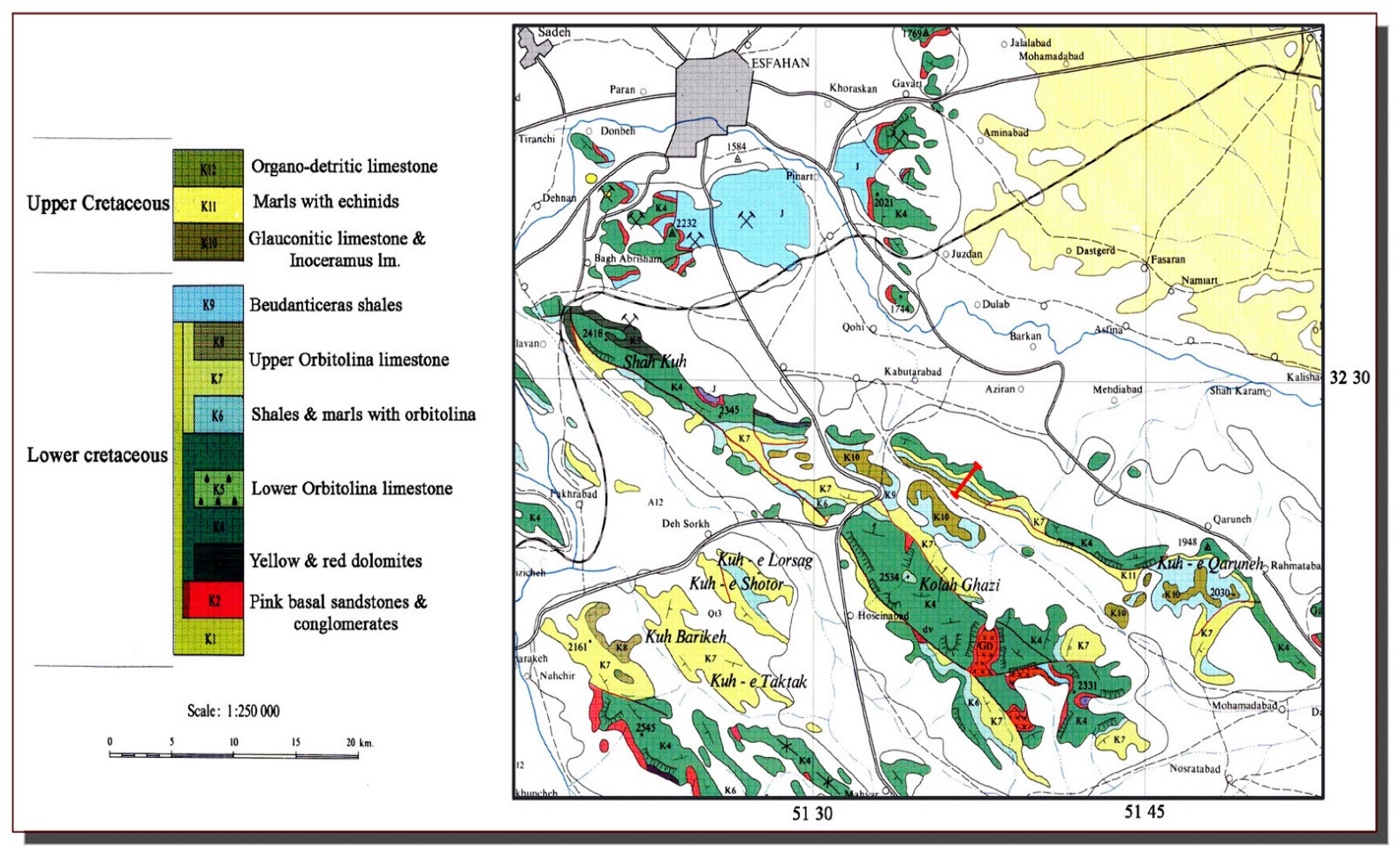

Figure 1. Representation of cretaceous stratigraphic units (Baharestan section), Isfahan 1:250,000 map. 


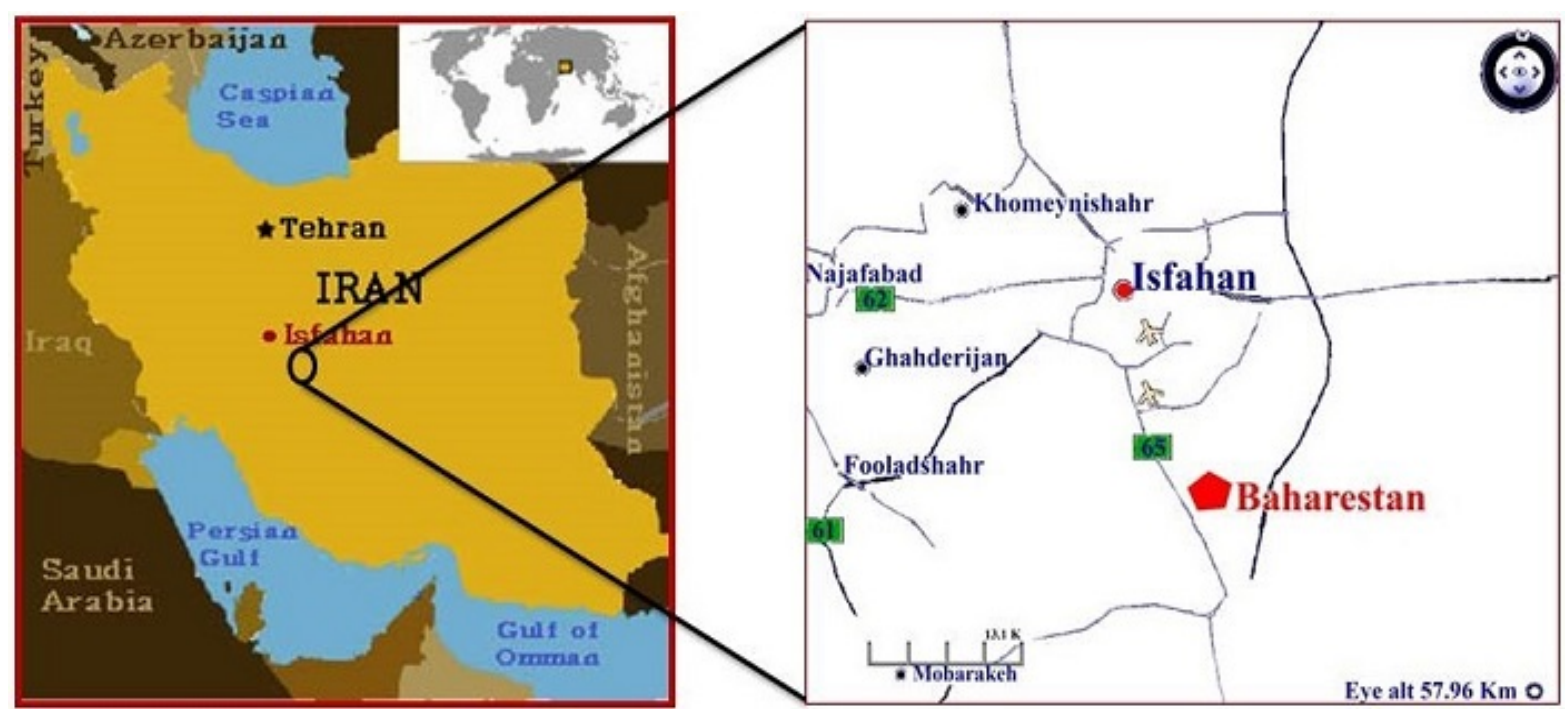

Figure 2. Baharestan cutting situation and access roads.

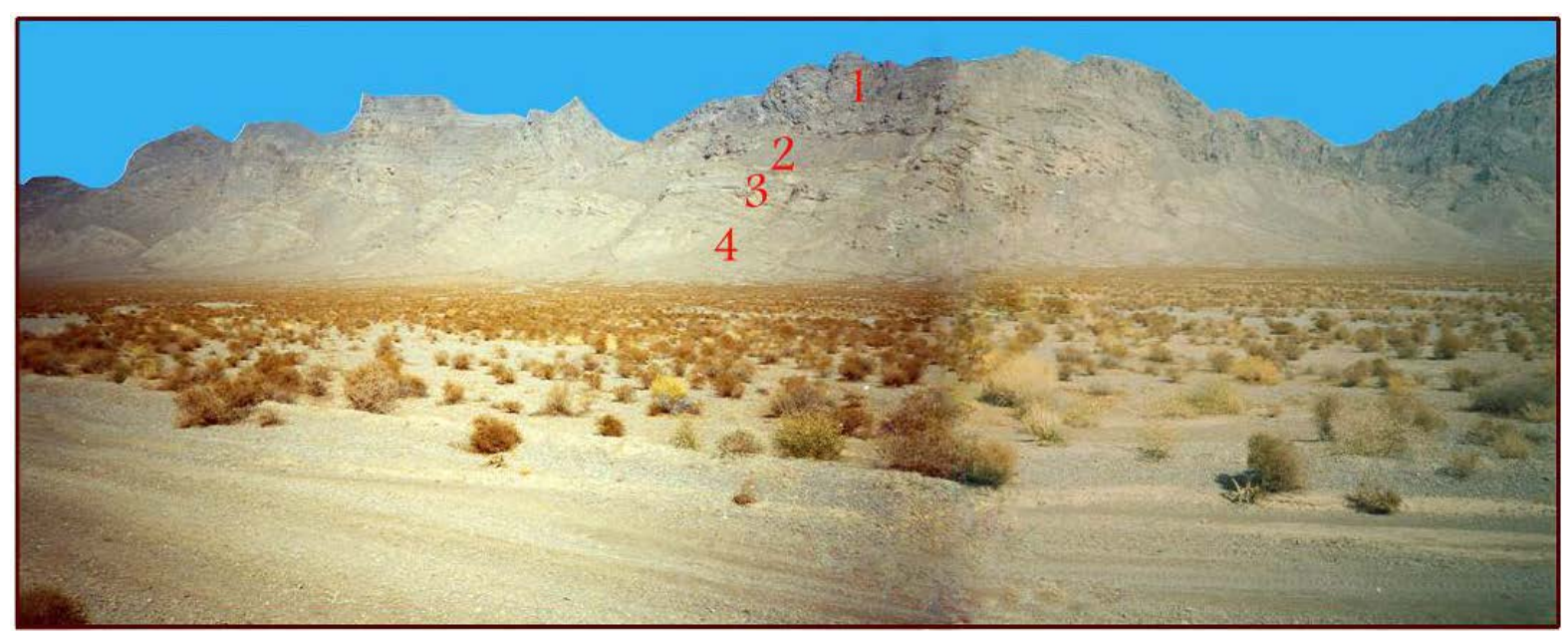

Figure 3. Baharestan section: 1: Orbitolina limestone unit; 2: Budanti saras shale unit; 3: Inoceramuos limestone unit; 4: Echinids marls unit.

\begin{tabular}{rlr}
\hline 1 & Medium to thin bedded, dark gray limestone & $1.7 \mathrm{~m}$ \\
2 & Thin bedded dark gray limestone & $3.3 \mathrm{~m}$ \\
3 & Limestone_-gray limy marl including bivalvia & $3 \mathrm{~m}$ \\
4 & Limestone_-gray limy marl & $4.2 \mathrm{~m}$ \\
5 & Limestone-medium to thin bedded gray limy marl & $5.3 \mathrm{~m}$ \\
6 & Limestone_-medium to thin bedded gray limy marl having bivalvia and crinoids & $4 \mathrm{~m}$ \\
7 & Gray limy marl & $24.9 \mathrm{~m}$ \\
8 & Thin bedded gray limy marl & $42.4 \mathrm{~m}$
\end{tabular}

This unit includes crinoid and planktonic foraminifers' species' fossils such as, Globotruncana, Globotruncanella, Globotruncanita, and Hedbergella/ and also benthic foraminifera (Loeblich and Tappan, 1988) [2], (Robaszynski and Caron, 1995) [3], (Robaszynski et al., 1984) [4]. 

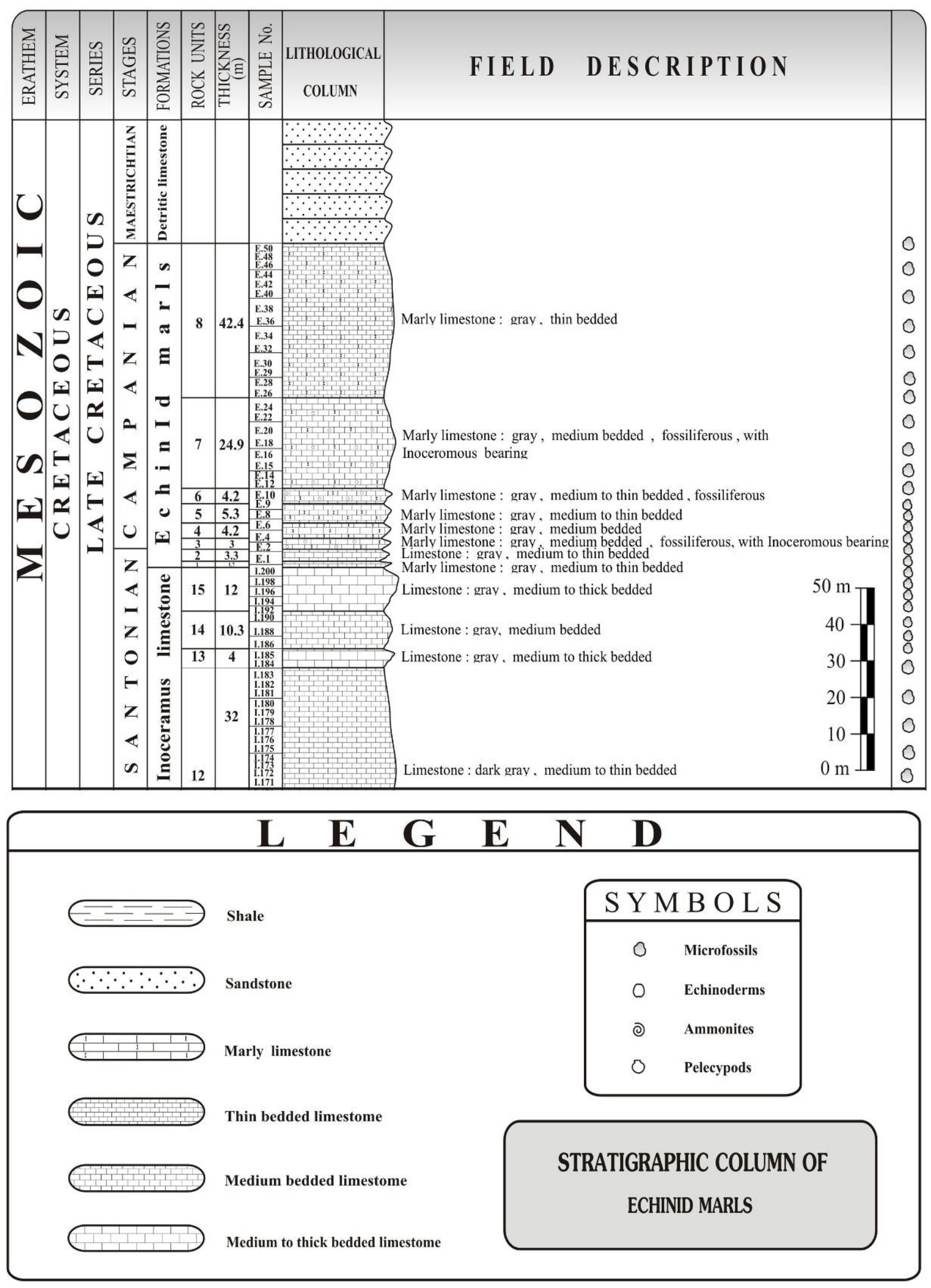

Figure 4. Sediment stratigraphic column santonian-campanian section baharestan. 
Biostratigraphy upper Cretaceous is consistent with Premoli Silva's (2004) biozone (Premoli Silva and Verga, 2004) [5], in Baharestan section:

Biozone 1:

\section{Marginotruncana sigali-Dicarinella primitiva partial range zone}

This biozone has dedicated 5 meters of stratigraphy of Baharestan section.

Its lower boundary is determined by last occurrence of Helvetoglobotruncana helvetica (Bolli) indicator of middle Turonian and upper boundary by first occurrence of Dicarinella concavata (Brotzen) upper part of middle Turonian.

The most important microfossils presented in this biozone are: (Bolli et al., 1994) [6], (Bolli et al., 1985) [7], (Li and Keller, 1999) [8], (Caron, 1985) [9].

Dicarinella canaliculata (Reuss), Dicarinella imbricata (Mornod), Dicarinella algeriana (Caron), Dicarinella hagni (Scheibnerova), Heterohelix sp., Marginotruncana renzi (Gandolfi), Muricohedbergella sp., Marginotruncana marianosi (Douglas), Marginotruncana pseudolinneiana Pessagno, Marginotruncana coronata, Whiteinella paradubia (Sigal).

Concerning the extinction of Helvetoglobotruncana helvetica (Bolli) at the middle Turonian and appearance of Dicarinella concavata (Brotzen) species the late Turonian and existing fossil society, the age of this biozone has been determined as Late middle to late Turonian.

Caron, 1985 believes this biozone is formed from two biozones showed below: (Bolli et al., 1985) [7], (Li and Keller, 1999) [8].

1) Marginotruncana sigali partial range zone

Age: Late Turonian

2) Dicarinella primitiva interval zone

Age: Late Turonian-Early Coniacian

Biozone 2:

Dicarinella concavata interval zone

This biozone has allocated 9 meters of stratigraphy column after biozone 1 of Baharestan section.

The low boundary is determined with first occurrence of Dicarinella concavata (Brotzen) and its upper boundary is marked with first occurrence of Dicarinella asymetrica (Sigal).

Fossil assemblage in this zone is accompanied by Marginotruncanids and has become dominant by lots of Whiteinellids.

The most important microfossils presented in this biozone are:

Dicarinella concavata (Brotzen), Dicarinella primitiva (Dalbiez), Dicarinella imbricata (Mornod), Heterohelix sp., Muricohedbergella sp., Marginotruncana coronata (Bolli), Marginotruncana schneegansi (Sigal), Marginotruncana pseudolinneiana Pessagno, Marginotruncana sigali (Reichel) Marginotruncana renzi (Gandolfi), Whiteinella baltica Douglas \& Rankin.

Concerning the appearance of Dicarinella concavata (Brotzen) species in the Early late Coniacian and appearance of Dicarinella asymetrica (Sigal) species in Early Santonian and existing fossil assemblage, the age of this biozone has been determined Late Turonian to earliest Santonian (Plate 1).

\section{Biozone 3:}

\section{Dicarinella asymetrica total range zone}

This biozone has allocated 11 meters of stratigraphy in Baharestan section after biozone 2 .

The lower boundary is indicated with the first occurrence of Dicarinella asymetrica (Sigal) and upper boundary with the last occurrence of Dicarinella asymetrica (Sigal) species.

This zone includes the last occurrence of Whiteinella. As well the upper boundary of this zone is coincided with the extinction of all Dicarinella.

The most important microfossils presented in this biozone are:

Archaeoglobigerina cretacea (d’ Orbigny), Dicarinella primitiva (Dalbiez), Dicarinella imbricata (Mornod) Heterohelix sp., Muricohedbergella sp., Macroglobigerinelloides sp., Marginotruncana coronata (Bolli), Marginotruncana schneegansi (Sigal) Marginotruncana pseudolinneiana Pessagno, Marginotruncana sigali (Reichel) Marginotruncana renzi (Gandolfi), Whiteinella inornata (Bolli), Lenticulina sp.

Based on this identified assemblage and presence of Dicarinella asymetrica (Sigal) species in this biozone, the age of this biozone has been determined Early Santonian to earliest Campanian (Plate 2).

\section{Biozone 4:}




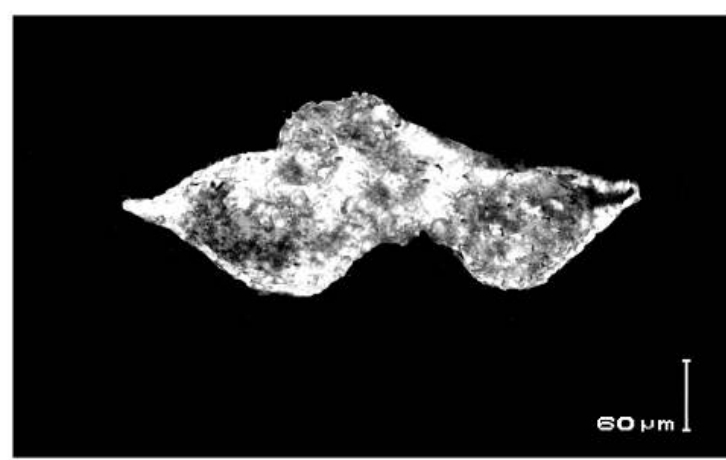

1

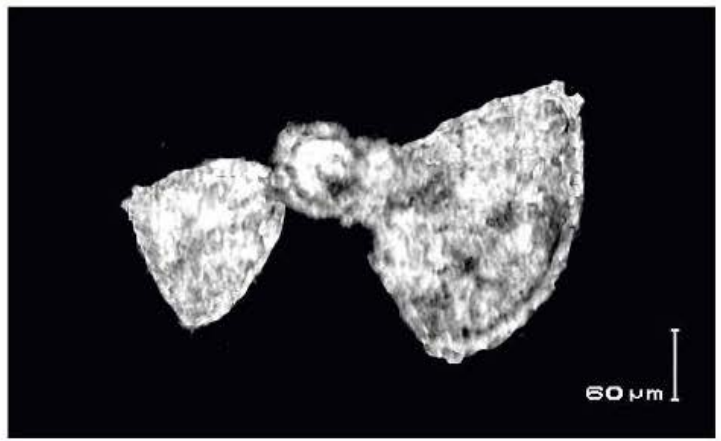

3

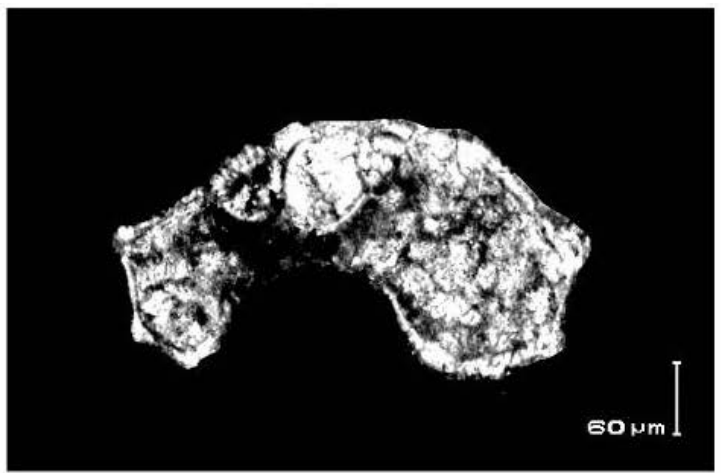

5

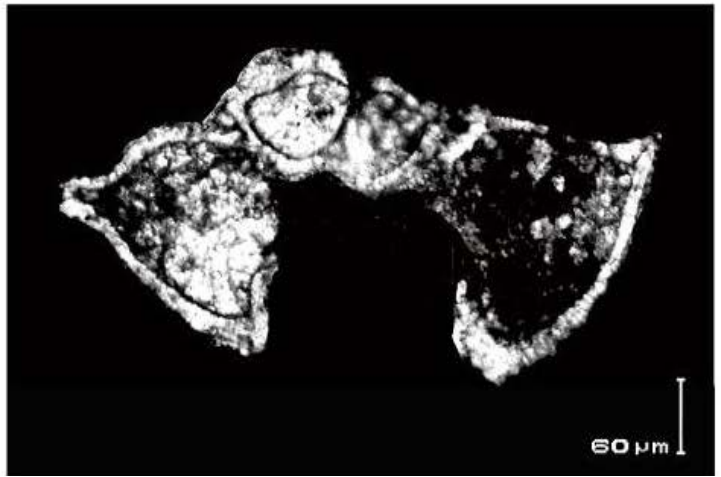

7

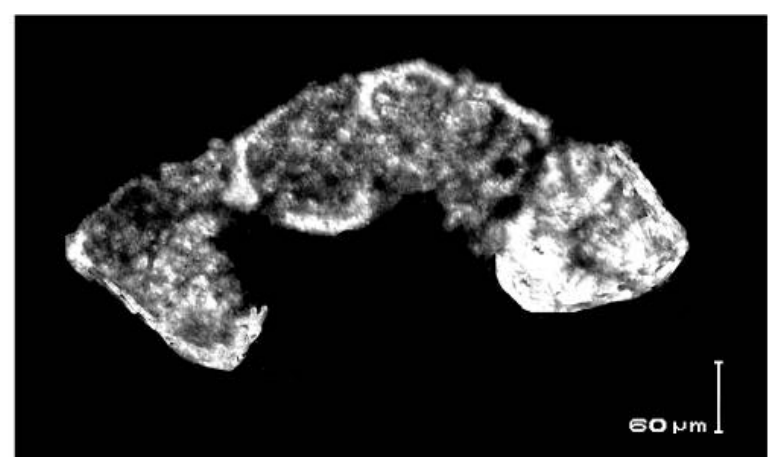

2

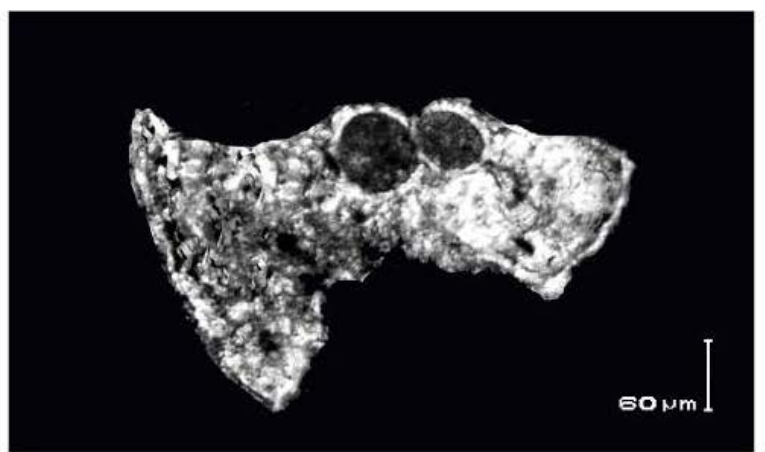

4

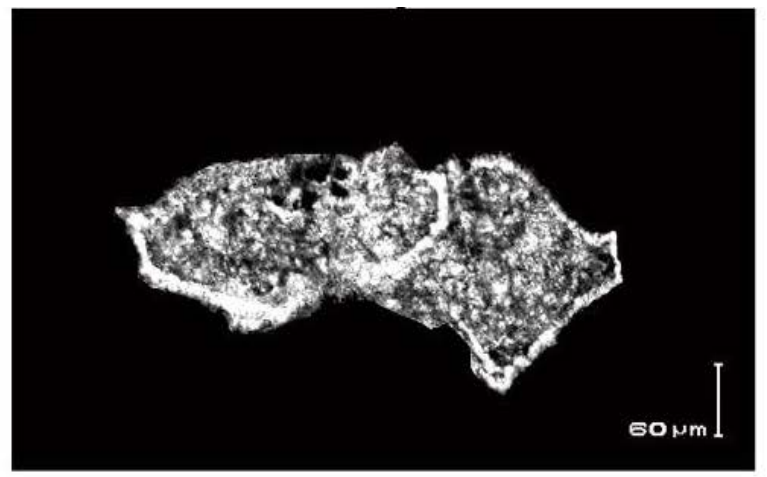

6

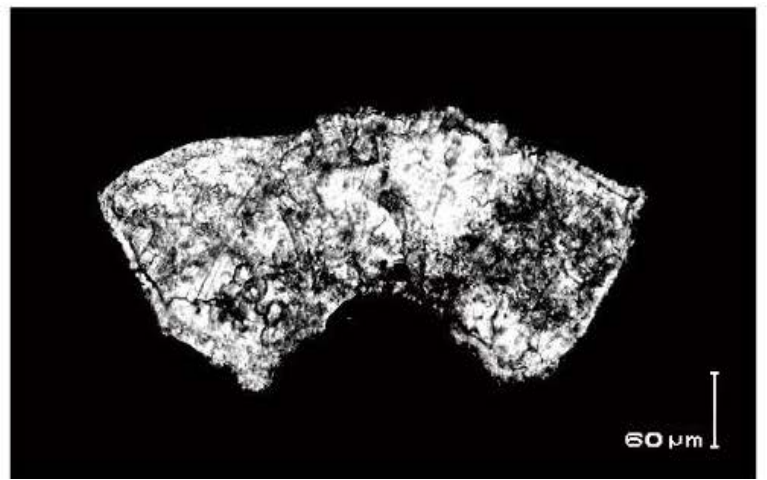

8

Plate 1. 1: Dicarinella primitiva (Dalbiez), Early Santonian; 2: Marginotruncana sigali (Reichel), Early Santonian; 3: Dicarinella concavata (Brotzen), Early Santonian; 4: Dicarinella asymetrica (Sigal), Santonian; 5: Globotruncanita elevata (Brotzen), Early Campanian; 6: Globotruncana ventricosa White, Campanian; 7: Radotruncana calcarata (Cushman), Late Campanian; 8: Globotruncanita stuarti (de Lapparent), Campanian. 


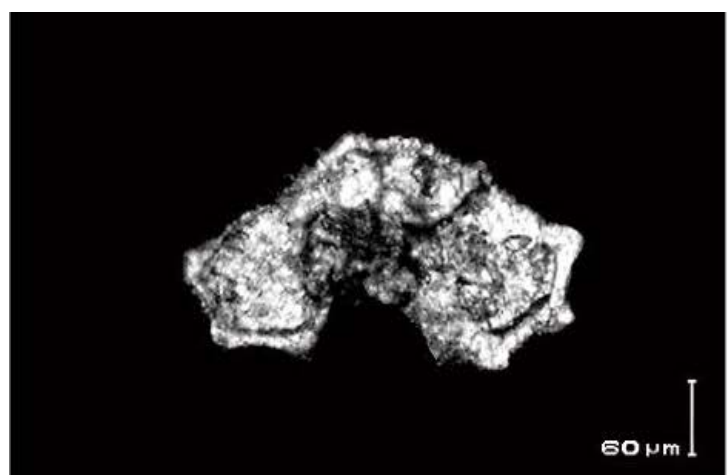

1

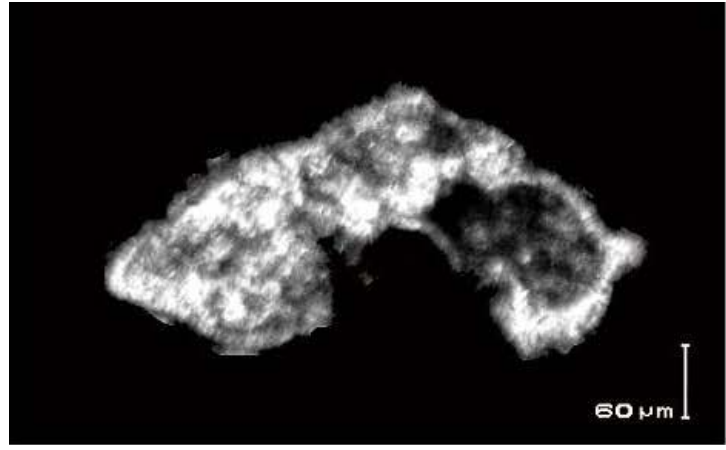

3

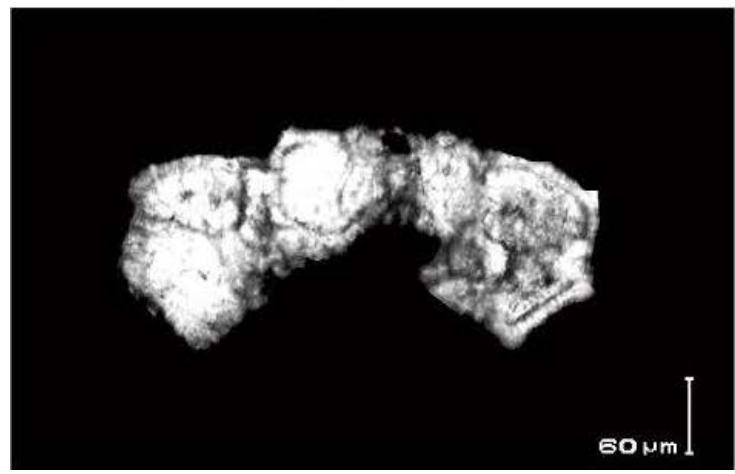

5

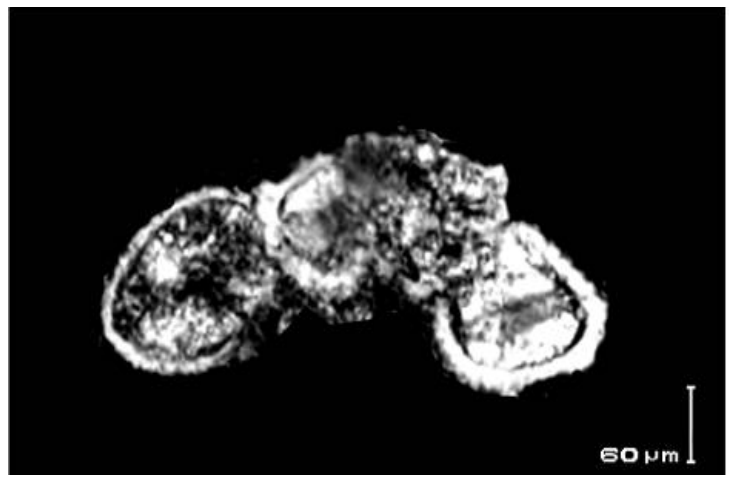

7

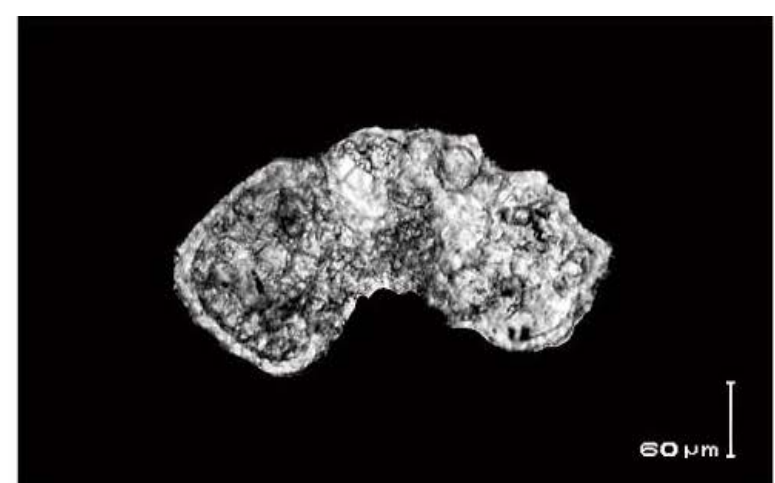

2

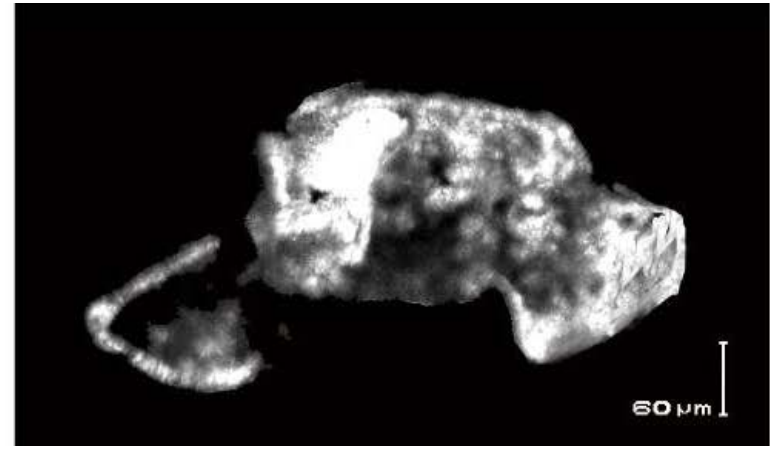

4

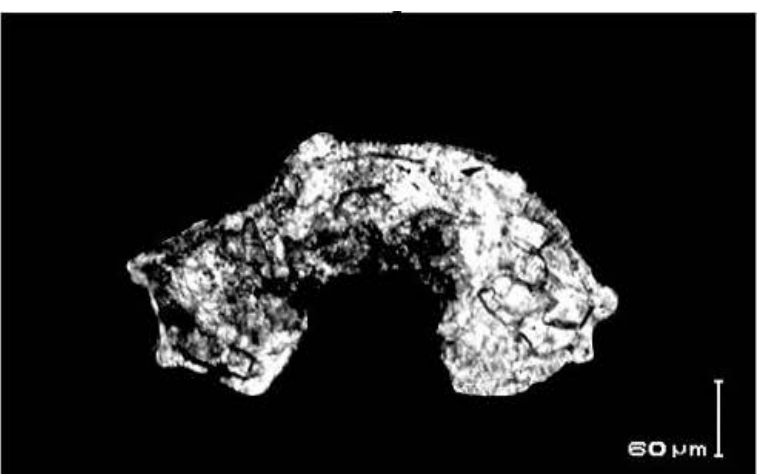

6

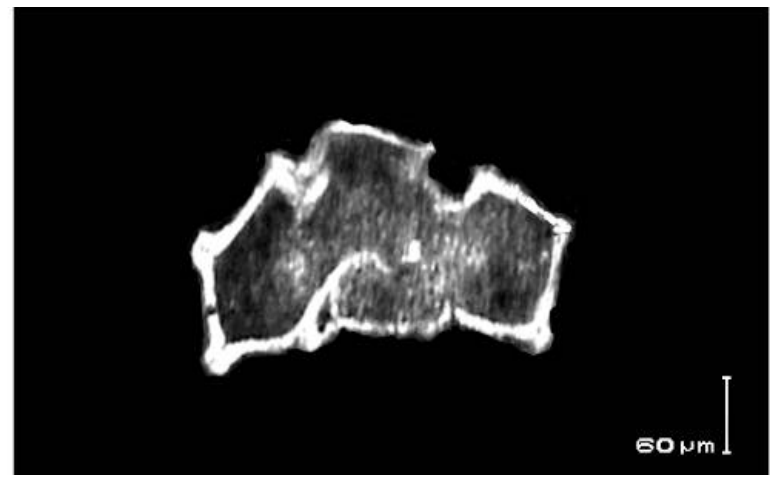

8

Plate 2. 1: Globotruncana arca (Cushman), Late Campanian; 2: Globotruncana bulloides Vogler, Santonian; 3: Contusotruncana fornicata (Plummer), Santonian-Campanian; 4: Marginotruncana renzi (Gandolfi), Santonian; 5: Globotruncana linneiana (d’Orbigny), Campanian; 6: Marginotruncana schneegansi (Sigal), Campanian; 7: Dicarinella imbricata (Mornod), Santonian; 8: Globotruncana lapparenti Brotzen, Campanian. 


\section{Globotruncanita elevata partial range zone}

This biozone has assigned 12.5 meters of stratigraphy in Baharestan section after biozone 3 .

In the distance of presence of Globotruncanita elevata which the lower boundary is recognized by extinction of Dicarinella asymetrica (Sigal) species and actually extinction of all Dicarinella and upper boundary from first occurrence of Globotruncana ventricosa (White).

The last occurrence of Marginotruncana is registered in the lower part of this zone.

The most important microfossils presented in this biozone are:

Archaeoglobigerina cretacea (d’ Orbigny), Archaeoglobigerina sp., Contusotruncana fornicata (Plummer), Macroglobigerinelloides sp., Globotruncanita elevata (Brotzen), Globotruncana arca (Cushman) Globotruncana lapparenti Brotzen, Globotruncana bulloides Volger Globotruncana linneiana (d’ Orbigny), Marginotruncana coronata (Bolli) Globotruncanita stuartiformis (Dalbiez).

Based on the presence of Globotruncanita elevata (Brotzen) and identified fossil assemblage in this biozone the age of this biozone has been Early Campanian.

\section{Biozone 5:}

\section{Globotruncana ventricosa interval zone}

This biozone has assigned 28.5 meters of stratigraphy in Baharestan section after biozone 4.

Definition: in the interval between the first occurrence of Globotruncana ventricosa to the first occurrence of Radotruncana calcarata.

The most important microfossils presented in this biozone are:

Archaeoglobigerina cretacea (d’ Orbigny), Archaeoglobigerina blowi Pessagno, Contusotruncana fornicata (Plummer), Heterohelix sp., Macroglobigerinelloides sp., Globotruncana lapparenti Brotzen, Globotruncana bulloides Volger, Globotruncana linneiana (d’ Orbigny) Globotruncanita stuartiformis (Dalbiez), Globotruncana arca (Cushman) Globotruncanita elevata (Brotzen), Globotruncana ventricosa (White), Pseudotextularia sp.

The age of this biozone is dedicated as the Middle to late Campanian.

\section{Biozone 6:}

\section{Radotruncana calcarata total range zone}

This biozone has consigned 23 meters of stratigraphy in Baharestan section after biozone 5.

Definition: Total range Zone of Radotruncana calcarata.

The lower boundary is indicated with the first occurrence of Radotruncana calcarata and upper boundary with the last occurrence of Radotruncana calcarata species.

The identification of the named taxa in the thin section is difficult because the correct identification of that need a special cut that has passed through the acicula (Premoli Silva \& Verga, 2004) [5].

The most important microfossils presented in this biozone are:

Contusotruncana fornicata (Plummer), Heterohelix sp., Macroglobigerinelloides sp., Muricohedbergella sp., Globotruncana bulloides Volger, Globotruncana linneiana (d’ Orbigny) Globotruncana arca (Cushman), Globotruncana lapparenti Brotzen Globotruncanita stuartiformis (Dalbiez), Globotruncanita elevata (Brotzen) Globotruncanita stuarti (de Lapparent), Pseudotextularia sp.

The age of this biozone is indicated as the Late Campanian in the studying section.

And types of Oligosteginia echinids marls comprise:

Calcisphaerula innominata lata Adams, Pithonella ovalis (Kaufmann, 1851) Calcisphaerula innominata (Kaufmann, 1865).

In the surveys that took place by authors the age of echinids marls concerning the found fossils was determined late Turonian-Campanian (Figure 5).

\section{Determining the Relative Paleobathymetry Changes}

In order to allocate the relative change of the fossils at the couch of sediments in the studying area, the most attention was to the changes among foraminifera microfossils.

Various investigations from the relativity of planktonic to benthic were used to identify the changes in the level of the water in the deposits of medium depth and deep areas.

Van der Zwaan et al. (1990) [10], have suggested the below formula for determining the depth (Van der Zwaan et al., 1990) [10], (Van der Zwaan et al., 1999) [11]. 


\begin{tabular}{|c|c|c|c|c|c|c|}
\hline कूँّ & Age & $\begin{array}{c}\text { This study in comparable } \\
\text { Premoli, Silva, } 2004\end{array}$ & (Caron, 1985) & (Postuma, 1971) & Permoli, Silva, 2004 & Wynd, 1965 \\
\hline \multirow{6}{*}{ 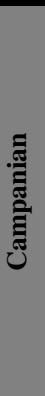 } & Late & \multirow{2}{*}{ Globotruncana aegyptiaca } & $\begin{array}{c}\text { Radotruncana } \\
\text { calcarata }\end{array}$ & $\begin{array}{c}\text { Radotruncana } \\
\text { calcarata }\end{array}$ & \multirow{2}{*}{$\begin{array}{c}\text { Globotruncana } \\
\text { aegyptiaca }\end{array}$} & \\
\hline & Middle & & $\begin{array}{c}\text { Globotruncana } \\
\text { ventricosa }\end{array}$ & & & \\
\hline & \multirow{4}{*}{ Early } & Globotruncanella havaensis & \multirow{4}{*}{$\begin{array}{c}\text { Globotruncanita } \\
\text { elevata }\end{array}$} & \multirow{4}{*}{$\begin{array}{l}\text { Globotruncana } \\
\text { elevata }\end{array}$} & $\begin{array}{c}\text { Globotruncanella } \\
\text { havaensis }\end{array}$ & \multirow{4}{*}{$\begin{array}{c}\text { Globotruncanita } \\
\text { elevata }\end{array}$} \\
\hline & & Radotruncana calcarata & & & $\begin{array}{c}\text { Radotruncana } \\
\text { calcarata }\end{array}$ & \\
\hline & & Globotruncana ventricosa & & & $\begin{array}{l}\text { Globotruncana } \\
\text { ventricosa }\end{array}$ & \\
\hline & & Globotruncanit elevata & & & $\begin{array}{c}\text { Globotruncanita } \\
\text { elevata }\end{array}$ & \\
\hline \multirow{2}{*}{ 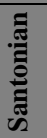 } & \multirow{2}{*}{ Late } & Dicarinella asymetrica & $\begin{array}{l}\text { Dicarinella } \\
\text { asymetrica }\end{array}$ & $\begin{array}{c}\text { Globotru ncana } \\
\text { carinata }\end{array}$ & $\begin{array}{l}\text { Dicarinella } \\
\text { asymetrica }\end{array}$ & $\begin{array}{c}\text { Globotruncana } \\
\text { concavata/ventricosa }\end{array}$ \\
\hline & & Dicarinella concavata & $\begin{array}{l}\text { Dicarinella } \\
\text { concavata }\end{array}$ & $\begin{array}{l}\text { Globotruncana } \\
\text { carinata }\end{array}$ & $\begin{array}{l}\text { Dicarinella } \\
\text { concavata }\end{array}$ & $\begin{array}{l}\text { Rotalia sp. 22-alga } \\
\text { Assemblage Zone }\end{array}$ \\
\hline
\end{tabular}

Figure 5. The comparison of studied biozones in Santonian-Campanian sediments (Baharestan) with other tetis area.

$$
\begin{aligned}
& \text { Depth }=e\left(3.58718+\left(0.03534 \times \% P^{*}\right)\right) \\
& \% P^{*}=(P / P+B-\text { infaunal }) \times 100
\end{aligned}
$$

$B$ is the number of benthic foraminifera and $P$ is the number of planktonic foraminifera.

Thus, in this study the percentage of planktonic foraminifera to the whole assemblage after omitting indwells benthonic foraminifera was used as the most important factor in determining the depth. Hence, in the presence of normal marine depositional conditions and the sample is not affected with the dissolution.

With reference to this equation the depth was determined about 200 - 450 meters for these sediments.

Generally the relative amount of benthic foraminifera with agglutinated test to hyaline test increases due to increasing depth. Also, the non-calcareous agglutinated test types show more depth than calcareous agglutinated test (Holbourn et al., 2001; Nagy et al., 2001) [12].

For the reason that planktonic foraminifera have less strength confronting the environmental changes than benthic foraminifera, they are more frequent in off shore. Since beaches have unstable situation and benthic foraminifera which have more strength and can bear the situation are seen in these areas (Sliter and Leckie, 1993) [13], (Li and Stinnesbeck, 1999) [14].

The relative of $P / B$ is identified according to equation $\% P^{*}=(P / P+B$-infaunal $) \times 100$. So that at the midTuronian to Santonian the proportion of Pelagic to benthic is 60 and in the Early Campanian, Globotruncanita elevata zone the proportion of Pelagic to benthic is 68 percent and in Globotruncana ventricosa zone this percentage is 71 and in Radotruncana calcarata zone the proportion reaches 80 percent.

\section{Depth Index Benthic Foraminifera}

In this method studying the depth in which they live, the patterns of social change and foraminifera species distributions toward the depth changes in different basins, dependent on depth species and the characteristics of benthic foraminifera in various depth are investigated, and finally it is assumed that forgoing species (if not extinct) or similar species have saved their living depth for ages. Then models for that special time is indicated that for instance it can be pointed to Sliter \& Baker (1972) which is one of the most popular model used for Cretaceous (Li and Stinnesbeck, 1999) [14], (Robaszynski and Caron, 1995) [3], (Figure 6).

Using the mentioned model or similar ones, one can determine nearly the depth of the under study fossils.

\section{Conclusions}

- Concerning the accurate studies on Campanian plankton foraminifera in studied section 11 types and 30 species have been identified.

- Presentation of 6 biozones appertain Globotruncanitas of Turonian-Campanian, coincided with biozone (Premoli Silva, 2004) [5]. 


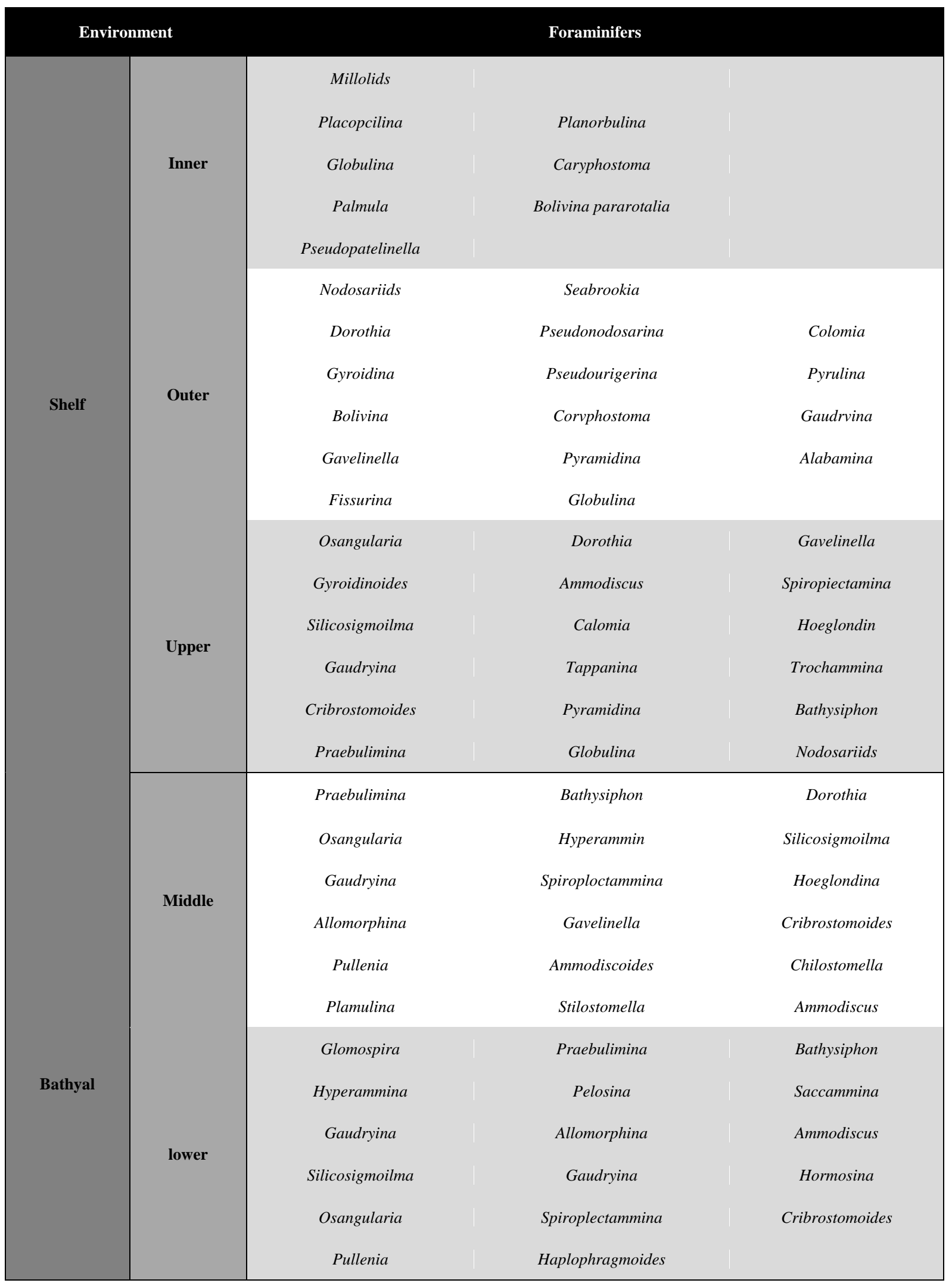

Figure 6. Cretaceous benthic foraminifera’ genera of deep scattering model (Sliter \& Baker, 1972) [13]. 
- To determine the depth of sediment of Turonian-Campanian at this time, planktonic and benthic foraminifera were studied. In this case, the percentages of foraminifera planktonic to the whole community of foraminifera after deleting indwell benthic foraminifera $\left(\% P^{*}\right)$ was identified using the equation $D=e\left(3.58718+\left(0.03534 \times \% P^{*}\right)\right)$ and a depth of 200 - 450 meters was concluded for these sediments.

\section{References}

[1] Aghanabati, A. (2005) Iran’s Geology, Geological Survey of Iran.

[2] Loeblich Jr., A.R. and Tappan, H. (1988) Foraminiferal General and Their Classification: Van Nostrand Reinhold Company, New Yourk, 2 Volumes, 970 p.

[3] Robaszynski, F. and Caron, M. (1995) Foraminiferes planctoniques du Cretace: Commentaire dela zonation EuropeMediterrane. Bulletin de la Societe Geologique de France, 166, 681-692.

[4] Robaszynski, F., Caron, M., Gonzales Donoso, J.M. and Wonders, A.A.H. (1984) Atlas of Late Cretaceous Globotruncanids. Revue de Micropaléontologie, 26, 145-305.

[5] Premoli Silva, I. and Verga, D. (2004) Practical Manual of Cretaceous Planktonic Foraminifera, Course 3. In: Verga, D. and Rettori, R., Eds., International School on Planktonic Foraminifera: Universities of Perugia and Milano, Tipografiadi di Pontefelcino, Perugia, 283 p.

[6] Bolli, H.M., Beckman, J.P. and Saunders, J.B. (1994) Benthic Foraminiferal Biostratigraphy of the South Caribbean Region. Cambridge University, Cambridge. http://dx.doi.org/10.1017/CBO9780511564406

[7] Bolli, M.H., Saunders, J.B. and Perch-Nielsen, K. (1985) Plankton Stratigraphy. Vol. I. Cambridge University Press, Cambridge, 87-154.

[8] Li, L. and Keller, G. (1999) Variability in Late Cretaceous Climate and Deep Waters: Evidence from Stable Isotopes. Marine Geology, 161, 171-190. http://dx.doi.org/10.1016/S0025-3227(99)00078-X

[9] Caron, M. (1985) Cretaceous Planktonic Foraminifera. In: Boli, et al., Plankton Stratigraphy, Cambridge University Press, Cambridge, 17-86.

[10] Van der Zwaan, G.J., Jorissen, F.J. and De Stigter, H.C. (1990) The Depth-Dependency of Planktonic/Benthic Foraminiferal Ratios; Constraints and Applications. Marine Geology, 95, 1-16. http://dx.doi.org/10.1016/0025-3227(90)90016-D

[11] Van der Zwaan, G.J., Duijnstee, I.A.P., Den Dulk, M., Ernst, S.R. and Kouwenhoven, N.T. (1999) Benthic Foraminifers: Proxies or Problems? A Review of Paleoecological Problems. Earth-Science Reviews, 46, 213-236. http://dx.doi.org/10.1016/S0012-8252(99)00011-2

[12] Holbourn, A., Kuhnt, W. and Soeding, E. (2001) Atlantic Paleobathymetry, Paleoproductivity and Paleocirculation in the Late Albian: The Benthic Foraminiferal Record. Palaeogeography, Palaeoclimatology, Palaeoecology, 170, 171196. http://dx.doi.org/10.1016/S0031-0182(01)00223-1

[13] Sliter, W.V. and Leckie, R.M. (1993) Cretaceous Planktonic Foraminifers and Depositional Environments from the Ontong Java Plateau with Emphasis on Sites 803 and 807. In: Berger, W.H., Kroenke, L.W., Mayer, L.A., et al., Proceedings ODP Science Results, 130, 63-84.

[14] Li, L., Keller, G. and Stinnesbeck, W. (1999) The Late Campanian and Maastrichtian in Northwestern Tunisia: Paleoenvironmental Inferences from Lithology, Macrofauna and Benthicforaminifera. Cretaceous Research, 20, 231-252. http://dx.doi.org/10.1006/cres.1999.0148 
Scientific Research Publishing (SCIRP) is one of the largest Open Access journal publishers. It is currently publishing more than 200 open access, online, peer-reviewed journals covering a wide range of academic disciplines. SCIRP serves the worldwide academic communities and contributes to the progress and application of science with its publication.

Other selected journals from SCIRP are listed as below. Submit your manuscript to us via either submit@scirp.org or Online Submission Portal.
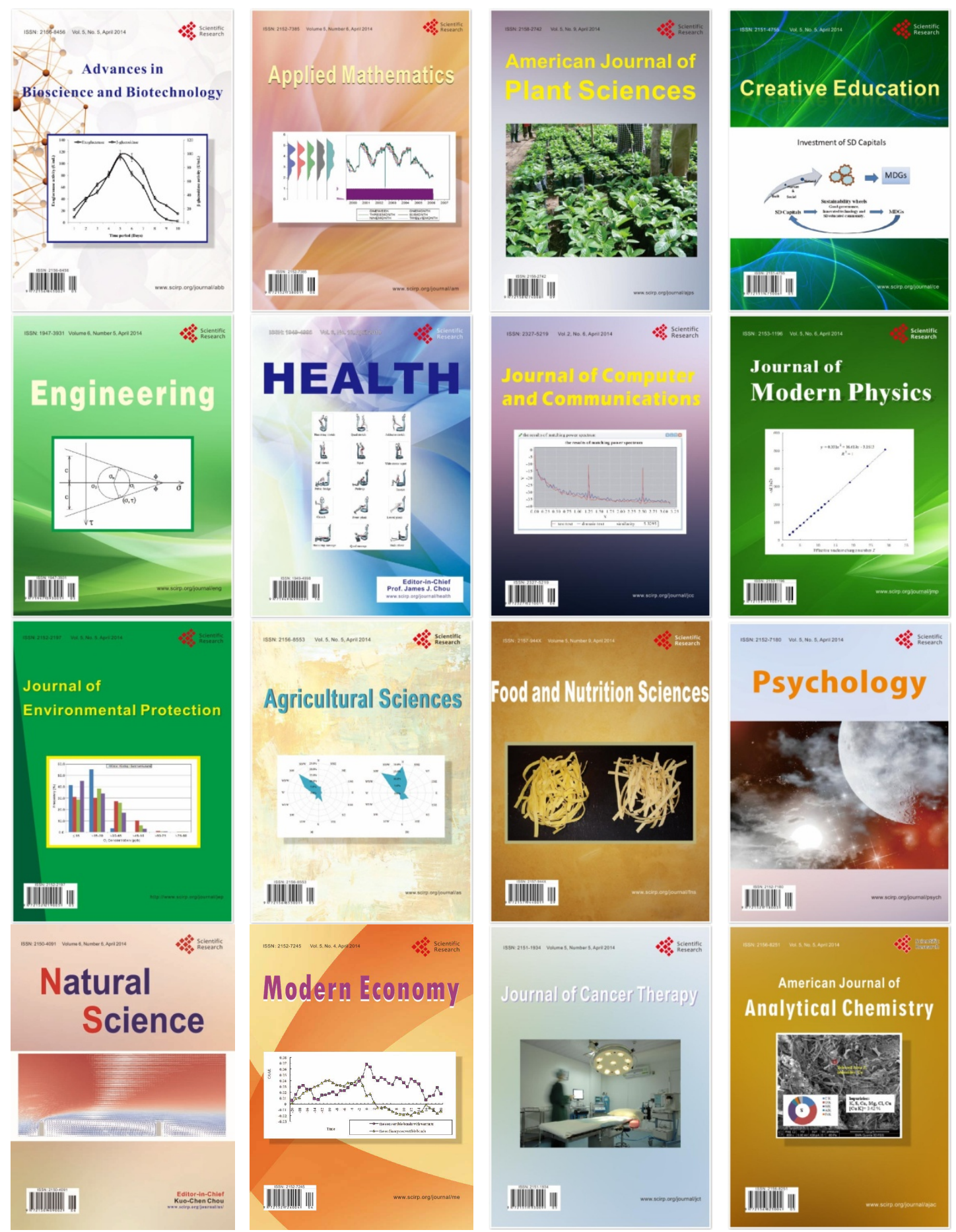